\title{
Land use-land cover changes and Mopani worm harvest in Mangwe District in Plumtree, Zimbabwe
}

Iphithule Ndlovu, Wilfred Njabulo Nunu* ${ }^{*}$, Nicholas Mudonhi, Oliver Dube and Auther Maviza

\begin{abstract}
Background: Mopani worms have been considered a critical food security resource as people living in Mopani woodlands depend on the worms both as a food source and as an income generating resource. These become a readily available substitute if agriculture fails and droughts loom. However the yields from these worms have been dwindling over the years and this has been associated with land use-land cover changes as the worms depend on vegetation. This research sought to investigate the relationship between land use-land cover changes and Mopani worm harvests in Mangwe District in Plumtree from the period 2007 to 2016 in Zimbabwe.
\end{abstract}

Methods: Satellite imagery was collected using LandSat 5 and LandSat 8 satellite and then classified using the SemiAutomatic Classification plugin in Quantum Geographic Information System to identify trees, dams, bare soil and settlements. Thematic maps were then produced and used to quantify extent of Land Use-Land Cover changes in the period from 2007 to 2016. Ground control data was collected using hand held Global Positioning System. Harvests trends (and reasons thereof) were estimated through usage of interviewer administered questionnaires on selected Mopani worm harvesters and harvest data kept by the community leaders.

Results: Results showed that settlements and bare soil cover had greatly increased from 2007 to 2016. There was a significant decline on vegetation cover from 2007 to 2016. There was also decline in the Mopani worm harvest over the years. Reasons for reduction of harvest were cited as deforestation, drought, overharvesting, cooking with lids on and occurrence of veld fires.

Conclusions: Findings of this study highlight that land use-land cover changes impacted negatively on Mopani worm harvests over the period 2007 to 2016 . It is also of paramount importance to note that major reasons for this decline has been associated with Land Use changes that are associated with human activities. There is need for Natural Resource Conservation Agencies to embark on awareness campaigns to encourage reforestation and also control cutting down of Mopani woodlands. Research needs to be conducted to determine the association between cultural beliefs and Mopani worm conservation and utilisation.

Keywords: Land-use, Land cover, Mopani worm, Harvest, Mangwe District, Zimbabwe

\footnotetext{
*Correspondence: njabulow@gmail.com

Department of Environmental Science and Health, National University

of Science and Technology, Corner Gwanda Road and Cecil Avenue

Ascot, P O Box AC 939, Bulawayo, Zimbabwe
} 


\section{Introduction}

Rural communities around the world rely on quite a number of resources for their survival and livelihoods (Makhado et al. 2012, 2014). These range from timber, grasslands, animals, insects and worms that they process and trade (Ryan et al. 2016). This reliance has been fuelled by poverty particularly in Sub Saharan Africa where majority of the populations live well below the poverty datum line (Beasley 2009). These communities barely afford the basics for survival therefore end up relying on these products for their livelihoods (Ajakaiye and Mwabu 2010).

Zimbabwe is among countries that have very rich biodiversity that sustain the livelihoods of local communities (Child 1996; Thompson et al. 2011; Chigonda 2018). A significant proportion of rural communities in Zimbabwe depends on biodiversity for development and improvement of their wellbeing (Chigonda 2018). Mopani trees and the Mopani worms are part of that biodiversity which improves people's livelihoods particularly in resource poor African countries like Zimbabwe (Makhado et al. 2012, 2014). In Zimbabwe the distribution and density of Mopani worms (Imbrasia Belina) largely follow that of the host plant Mopani tree (Colophosperum Mopani) (Makhado et al. 2012). Majority of these areas lie in regions that have low rainfall and the terrain is not suitable for cultivation and most of the people there rely on livestock production as a major source of income and survival (Child 1996; Potgieter et al. 2006). These areas presents challenges to the locals as there experience erratic rainfall patterns and harsh climatic conditions that normally lead to failure of staple grains increasing vulnerability to food insecurity (Ajakaiye and Mwabu 2010; Makhado et al. 2014). In Zimbabwe main areas of Mopani worm occurrence are in districts that are in the Southern region and are characterised as region four and five and receives the least amounts of rainfall as compared to other regions (Potgieter et al. 2006).

Traditionally, Mopani worms have been harvested for subsistence by rural household and they are make a significant contribution to rural diets as it has high protein content (Potgieter et al. 2012). Dried Mopani worms have high protein content with $65.8 \%$ dry weight crude protein content and $53.3 \%$ dry weight digestible protein (Potgieter et al. 2012; Makhado et al. 2012).

Mopani worm harvesting has become a source of food, employment and income in Mangwe District in Zimbabwe. The income from Mopani worm selling is normally used for different purposes such as purchasing grain, foodstuffs, paying school fees, paying medical bills, travel, although Mopani income on its own is insufficient to cover all these expenditures (Child 1996; Makhado et al. 2012). It should be noted that Mopani worm harvests in Mangwe District has dropped significantly over the years. There has been suspicions that LULC changes have impacted negatively on Mopani world yield (Dube 2015a, b). Monitoring of such LULC changes using GIS, provided a window of opportunity in understanding the dynamics in terms of land use-land cover changes influence Mopani worm yield (Dube 2015b). This study therefore investigated the effects of LULC changes on Mopani worm harvest in Mangwe District in Plumtree, Zimbabwe.

\section{Methods \\ Study area}

Mangwe is a district located in Matabeleland South Province, in the South-Western Zimbabwe close to the international border with Botswana. Its main town is Plumtree which is located about 100 kilometres, by road southwest of Bulawayo the nearest large city. At an altitude of 1387 meters, above sea level the district is classified as a Region four and five characterised by low rainfall of about $500 \mathrm{~mm}$ and high temperatures reaching 40 degrees Celsius during summer and an average of 13 degrees Celsius during winter (Government of Zimbabwe 2016; Dube 2015a). The dry season is very long in this district lasting form April to October (Chemura et al. 2016; Dube 2015a). Such an area is suitable for extensive farming such as cattle or game ranching. The district houses a population of approximately 93,000 (Government of Zimbabwe 2016). There is a lot of out-migration as most people migrate to neighbouring countries in search of jobs and other sources of livelihoods (Government of Zimbabwe 2016). However the epicentre where the Mopani worms were abundant was in Ward 4 known as Sanzukwi. Most harvesters including people from outside Mangwe District would converge to harvest these worms. All harvesters are recorded in the registers that are kept by the traditional leaders in those wards where harvesting occurs, with outsiders being charged a fee for harvesting in relation to the quantities that there would have harvested. The map of the district is captured as Fig. 1.

\section{Study design}

A mixed method cross sectional survey was conducted in Mangwe District through creation of satellite imagery and estimation of Mopani worm yield for the period 2007 to 2016. Furthermore respondents' views were gathered to explain the Mopani worm patterns on the same period under review.

\section{Study population}

All Mopani worm harvesters who resided in any of the wards in Mangwe from 2007 to 2016 and have been 


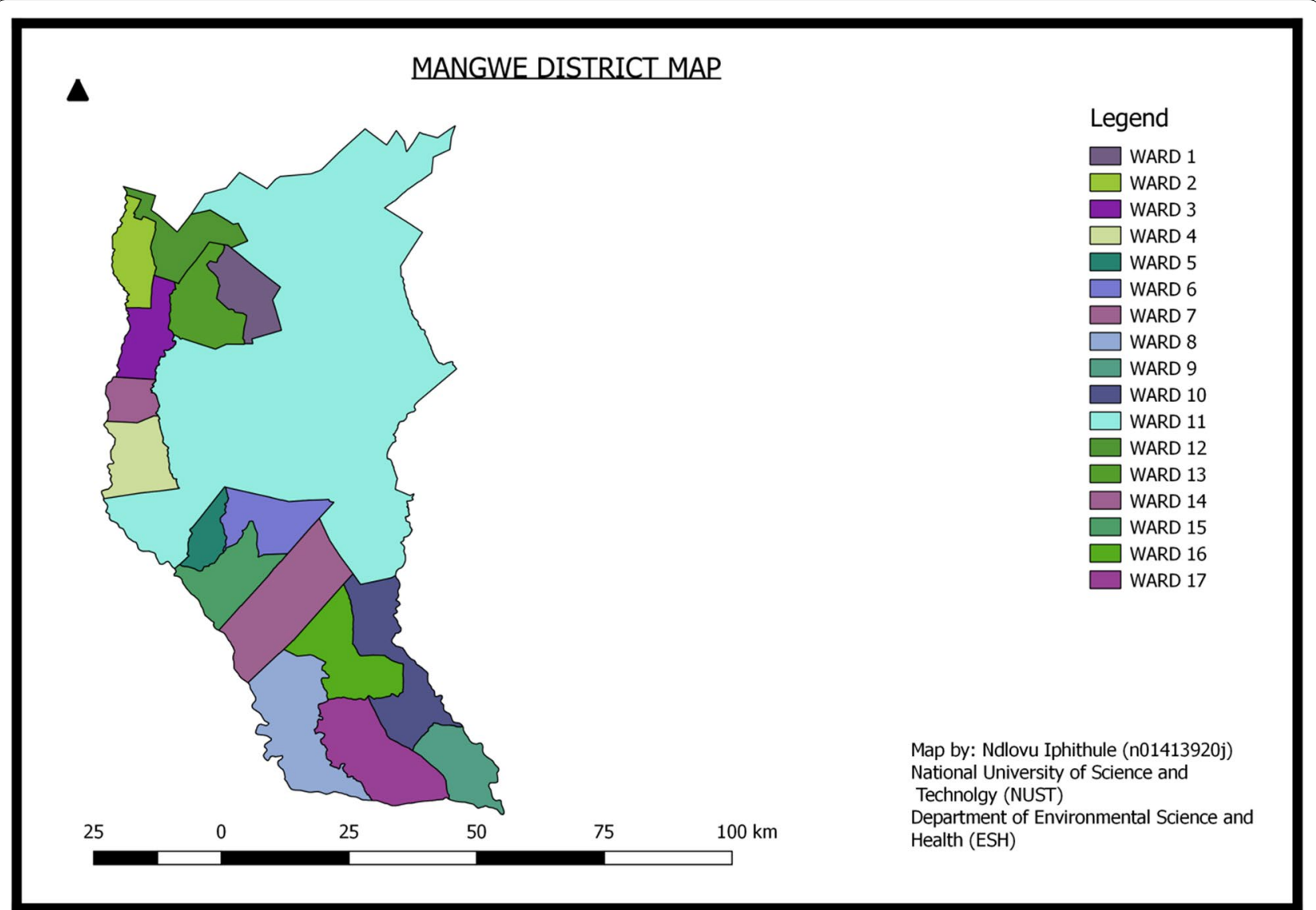

Fig. 1 Study area map (Mangwe District showing all wards)

harvesting worms in the specified time period were eligible to be part of the study.

\section{Sampling}

Since it was difficult to establish the exact total number of Mopani Worm harvesters, a sample size calculator on EPI INFO was employed. The population size was treated as unknown, at $90 \%$ confidence interval with a confidence width of $10 \%$ and an expected value of attribute of $50 \%$. This gave a targeted sample size of 68 which was then rounded off to 70 . Snowballing was used to locate and recruit the targeted 70 individuals in any of the wards in Mangwe District.

\section{Data collection}

For mapping, satellite images (from Landsat 5 and Landsat 8 systems) were downloaded from Earth Explorer. Ground control data was acquired using Garmin etrex handheld GPS devices. Data from Mopani worm harvesters was collected using a researcher administered questionnaire with both open and closed questions. Secondary data on quantities harvested was also collected from records kept by community leaders in different wards. The collected data (from questionnaires and from records) was used to estimate Mopani worm harvests for the period 2007 to 2016 and to solicit for explanations on quantities of Mopani worms harvested in the period under review. The two different data sources were used to triangulate and get an estimate that was closer to the truth.

\section{Data analysis}

QGIS 2.14 and a Semi-Automatic Classification plug in were used to generate maps for LULC changes using data obtained from Earth Explorer. QGIS was also used to separately classify data into four classes i.e. settlements, bare soil, dams and trees. Change detection was done using SCP; the LULC changes raster maps were ingested into QGIS and the SCP tools used to compare the 2016 map with the 2007 map resulting in the production of a table with pixel sum. This enabled the percentage and area changes to be determined. Accuracy was tested using GPS coordinates collected from the study area which were overlaid with the 2016 map and verification 
made on the Land Use that was obtaining in that specific location. Mopani worm harvest estimates were determined through a combination of triangulated data. Firstly harvests that were recorded by community leaders in all wards were populated and converted into volumetric quantities (cubic centimetres) these were then compared with harvest estimate data collected from the 70 respondents that were also converted into cubic centimetres. For example a $20 \mathrm{l}$ bucket worth of harvest was treated as $20 \mathrm{~cm}^{3}$, with different containers calibrated in relation to the $20 \mathrm{l}$ bucket. The data was then used to estimate yield for the specified period (2007-2016). Respondents were also asked to give their views regarding quantity trends of harvested Mopani worms over the period under review. Respondents were expected to give their major reason that they thought could have influenced the trends that were obtaining during data collection. Their responses were collated and analysed and proportions calculated and presented in a pie chart.

\section{Results}

LULC changes in the period 2007 to 2016

Settlements grew significantly from the year 2007 to 2016. This resulted in reduction of vegetation cover including Mopani woodlands. Most of the bare soil was also converted into settlements. These findings are presented in Figs. 2 and 3.

\section{Percentage changes in different land use classes}

Findings of the study point out that the overall percentage change in LULC is estimated at $34 \%$. The percentage change in trees was significantly higher as most woodlands had been converted into settlements which were accounting $48 \%$ of the land that was previously woodlands in 2007. The category for dams did not change much as compared to other categories as the land that was identified as dams in 2007 only $17 \%$ had been converted to other Land uses other than dams. These findings are presented in Table 1 and Fig. 4.

\section{Mangwe District Landuse Landcover Map 2007}

Legend

Trees

Dam

Baresoil

Settlements

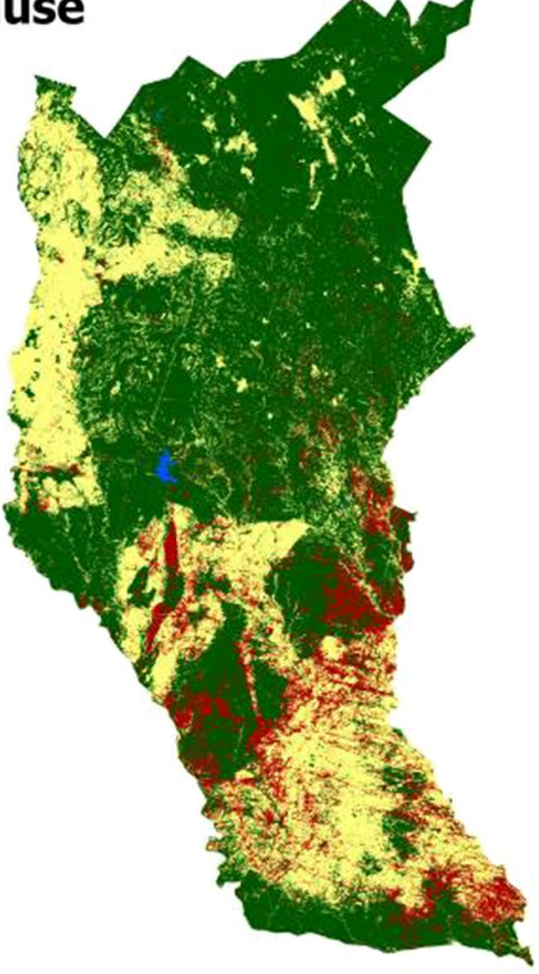

$\begin{array}{llllll}10 & 0 & 10 & 20 & 30 & 40\end{array}$

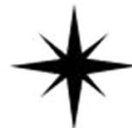

$\mathbf{N}$

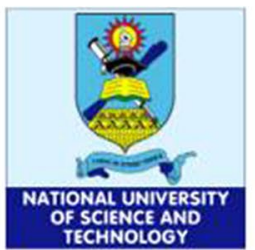

Map prepared by: Iphithule Ndlovu NUST, Zimbabwe 07/05/18

CRS: WGS 84

Fig. 2 LULC map 2007 


\section{Mangwe District Landuse Landcover Map 2016 \\ use}

Legend

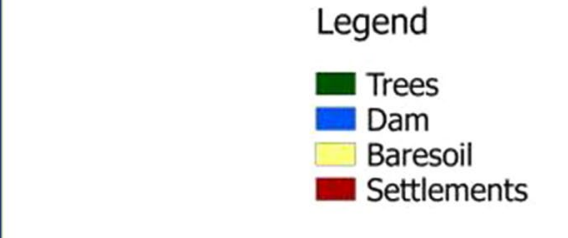

8
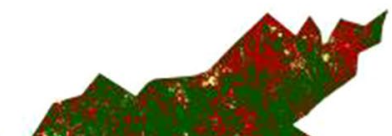

(1)
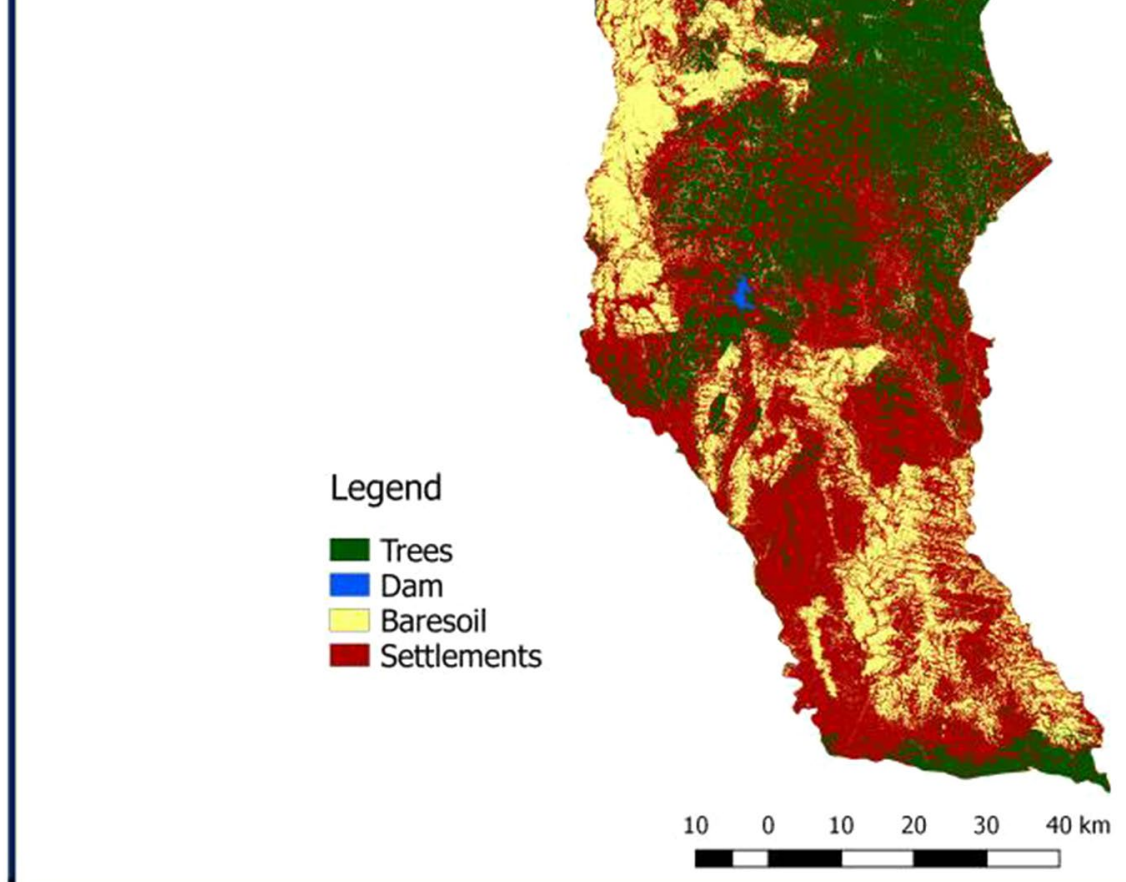

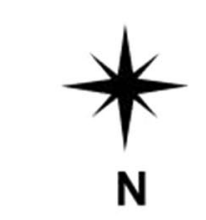

Map prepared by:

Iphithule Ndlovu

NUST, Zimbabwe

07/05/18

CRS: WGS 84

Fig. 3 LULC map 2016

Table 1 Percentage change of the LU (1.0: trees, 2.0: dams, 3.0: bare soil, 4.0: settlement)

\begin{tabular}{|c|c|c|c|c|}
\hline $\begin{array}{l}\text { Reference } \\
\text { class (2007) }\end{array}$ & $\begin{array}{l}\text { New class } \\
(2016)\end{array}$ & Pixel sum & Area (km) & $\begin{array}{l}\text { Percentage } \\
\text { change (\%) }\end{array}$ \\
\hline \multirow[t]{4}{*}{1.0} & 1.0 & $1,879,160$ & 169.1244 & 50 \\
\hline & 2.0 & 300 & 0.027 & 0.008 \\
\hline & 3.0 & 76,686 & 6.90174 & 2 \\
\hline & 4.0 & $1,799,963$ & 161.99667 & 48 \\
\hline \multirow[t]{4}{*}{2.0} & 1.0 & 10 & 0.0009 & 0.12 \\
\hline & 2.0 & 6735 & 0.60615 & 83.7 \\
\hline & 3.0 & 34 & 0.00306 & 0.42 \\
\hline & 4.0 & 1265 & 0.11385 & 15.7 \\
\hline \multirow[t]{4}{*}{3.0} & 1.0 & 63,869 & 5.74821 & 3.35 \\
\hline & 2.0 & 11 & 0.00099 & 0.0006 \\
\hline & 3.0 & $1,104,760$ & 99.4284 & 58 \\
\hline & 4.0 & 737,604 & 66.38436 & 38.7 \\
\hline \multirow[t]{4}{*}{4.0} & 1.0 & 22,897 & 2.06073 & 3.35 \\
\hline & 2.0 & 1 & $9 * 10^{-5}$ & 0.0001 \\
\hline & 3.0 & 166,474 & 14.98266 & 24.3 \\
\hline & 4.0 & 495,134 & 44.56206 & 72.3 \\
\hline
\end{tabular}

\section{Mopani worm harvest estimations (2007-2016)}

Findings on estimates of Mopani worm harvests from 2007 to 2016 showed a significant drop in quantities. This is further supported by the regression analysis that showed a strong negative correlation $(-0.9695)$ between progression of time from 2007 to 2016 and the estimated harvests. This means that as time progressed from 2007 to 2016 there was significant drop in Mopani worm harvests. These findings are captured in Fig. 5.

\section{Harvester's perspectives on Mopani worm harvests}

The 70 respondents that were part of the study were further asked open ended questions to give their views on the estimation or trends they had observed regarding Mopani worm harvests in relation to Land use. All the respondents cited that they have seen a sharp decline on Mopani worm harvests. After being probed to give a major reason as to what could have influenced this trend, there were five themes that emerged from 


\section{Mangwe District LULC Change detection Map 2007 - 2016}

Legend

Most change(67-100\%)

Moderate change(34-66\%)

Less change $(0-33 \%)$

No change
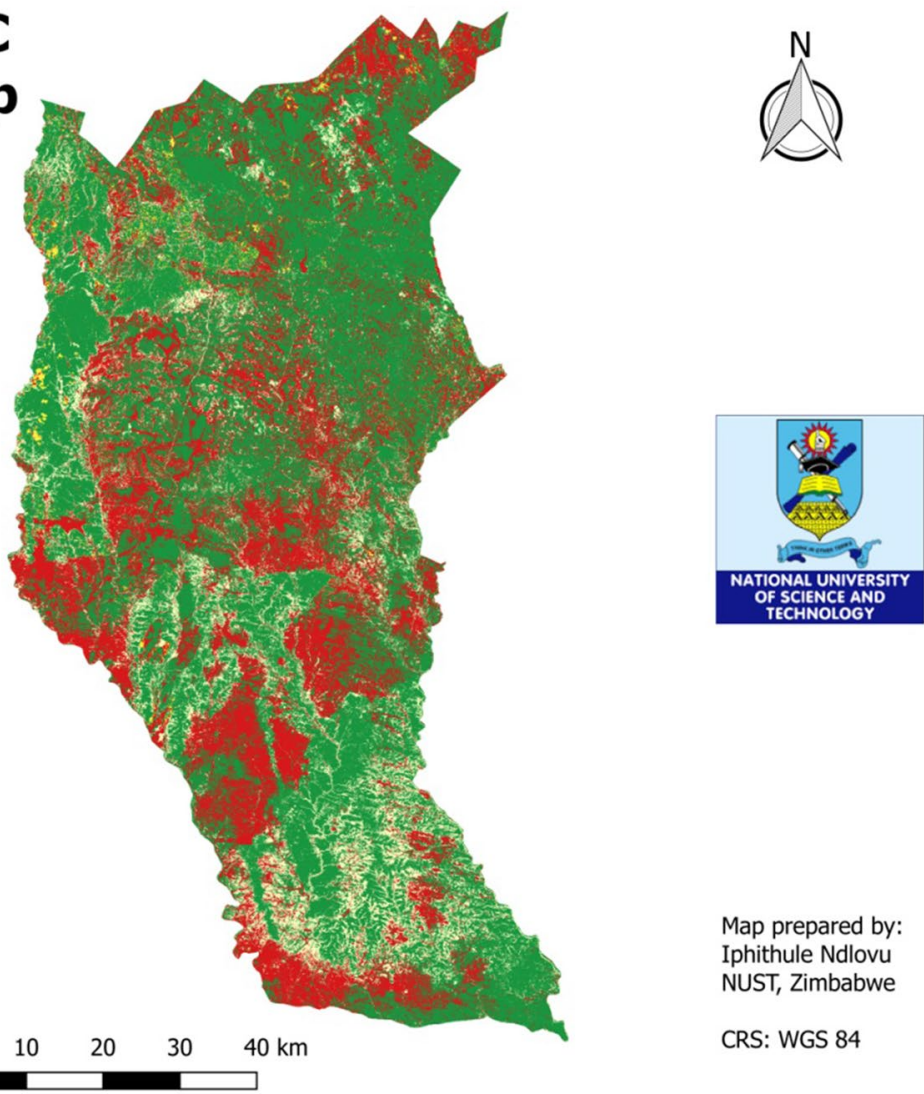

Map prepared by:

Iphithule Ndlovu

NUST, Zimbabwe

10

CRS: WGS 84

Fig. 4 Percentage change detection map

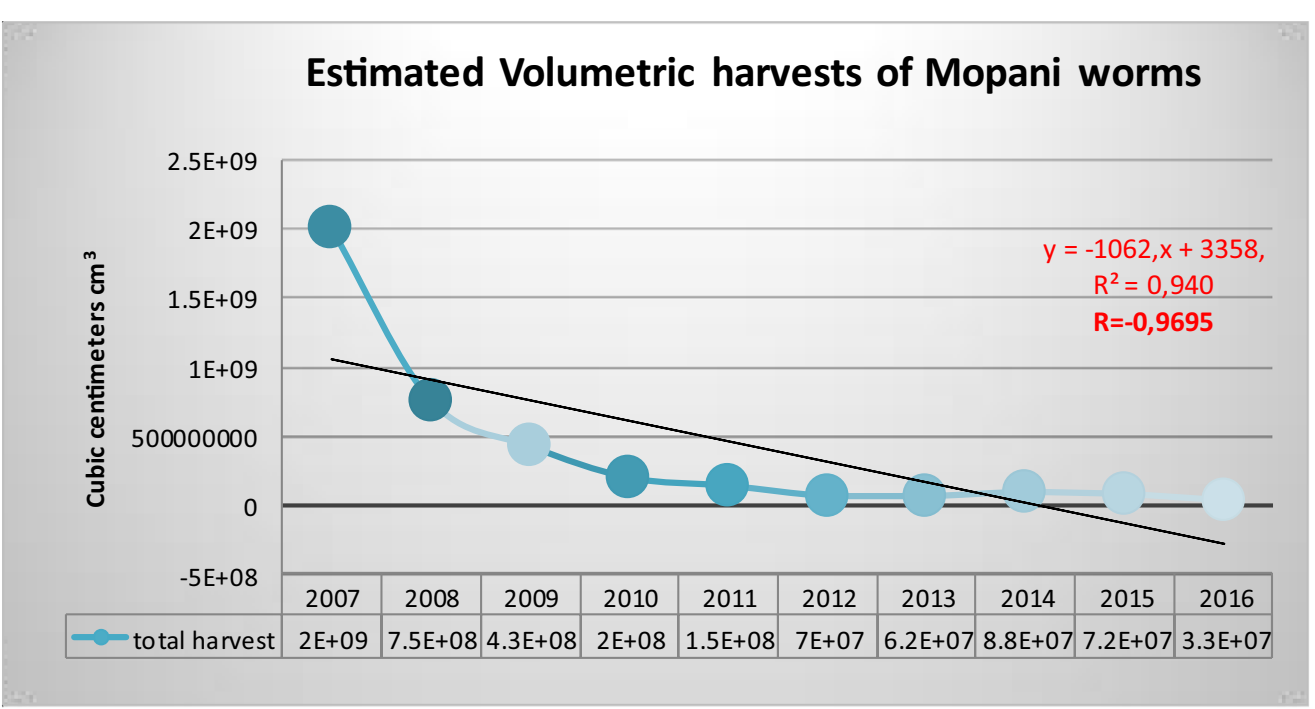

Fig. 5 Estimated volumetric harvests of Mopani worms 


\section{Reasons for Mopani worm harvest decline $(n=70)$}

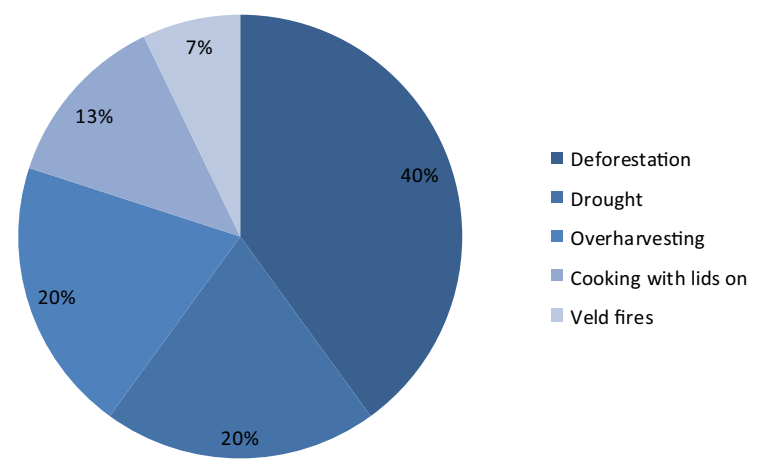

Fig. 6 Reasons for the Mopani harvest trends observed

their responses and these are presented below. These findings are also summarised as proportions in Fig. 6.

\section{Deforestation}

Most respondents $(40 \% ; n=70)$ cited that cutting down of Mopani trees and usage as a source of fuel has resulted in a decline in the yield of Mopani worms. Respondents elaborated that Mopani worms are dependent on Mopani trees, therefore the lesser the trees the lesser the harvest.

\section{Occurrence of droughts}

Some respondents $(20 \% ; \mathrm{n}=70)$ cited that rains that have been received of late are not as good as they used to be over a decade ago. It was further elaborated that severe droughts have impacted on the growth of vegetation including the Mopani tree which is the host tree for Mopani worms.

\section{Over harvesting the Mopani worms}

Another emerging reason $(20 \%$; $=70)$ was that overharvesting of Mopani worms led to their quantities to dwindle. Respondents cited that as you over harvest you reduce the chances of the worms turning into butterflies. They alluded that these butterflies are the ones that lay eggs that hatch into these Mopani worms for the coming harvesting season the following year.

\section{Cooking of Mopani worms with pot lids on}

Another theme that came up (13\%; $n=70)$, was the belief that some respondents had towards cooking and preparation of the Mopani worms. Respondents cited that according to their cultural beliefs when one is cooking the Mopani worms, the pot lid should not be on. If the worms are cooked with the pot lid on this causes reduction of the Mopani worm populations.

\section{Outbreaks of veld fires}

The last obtained reason from the remainder of the respondents $(7 \% ; n=70)$ was the outbreaks of veld fires during the dry seasons. They explained that during the dry season fires destroy Mopani trees that are the host trees for these worms. Some respondents further explained that, butterflies that lay eggs which hatch into Mopani worms are also destroyed during these fire outbreaks.

\section{Discussion}

There has been notable change in Mopani woodland vegetation cover in Mangwe District, findings presented in the 2007 map shows significant abundance of vegetation including Mopani woodlands compared to the map of 2016. The LU features were verified using control data collected using GPS and the findings were accurate. One of the key reasons that were noted for this decline by some respondents was the destruction of Mopani worm habitats due to deforestation. These findings are consistent with studies conducted by Makhado et al. (2012, 2014) which states that Mopani trees are usually preferred as a wood source of fuel because of its high heating efficiency compared to other woody species therefore where they are settlements the Mopani trees surrounding that settlement are usually excessively cut down (Makhado et al. 2012, 2014). Other authors concur that LU changes i.e. from woodlands to settlements bring about increased human activities such as agriculture resulting in clearance of vast amounts of land (Chikuni 1996; van Voorthuizen 1976; Wessels 1999; Potgieter et al. 2006).

Some respondents cited that though they are changes in LU that has been observed over the years, droughts also have been identified as a contributory factor to decline of harvests. These findings concur with findings from a study conducted by Mataboge et al. 2016, reported that climate changes (including droughts) impacts negatively on the survival of Mopani trees thereby directly influencing Mopani worm quantities as they are sorely dependent on Mopani trees for survival (Mataboge et al. 2016).

Respondents also cited that Mopani worm decline was caused by overharvesting. These findings are well supported by Thomas (Thomas 2013) in a study that was conducted in Northern Namibia (Thomas 2013). The author argues that if Mopani worms are to be conserved there is need for sustainable harvesting which minimises over exploitation (Thomas 2013). Over harvesting results in the disturbance of Mopani worm life cycles thereby reducing quantities of Mopani worm that turn into butterflies which in turn lay eggs that hatch into these 
worms (Thomas 2013). However poverty has resulted in over exploitation of natural resources as they are being used as a source of livelihoods in resource poor countries (Beasley 2009).

Outbreaks of fires which are also linked to human activities (settlements) were pointed out as another contributory factor that has resulted in reduction of yield of Mopani worms during the period under review. Studies have cited that usage of fires in land clearance for agricultural and other human activities has been strongly associated with huge losses of biodiversity with some being destroyed unintentionally (Clement and Horn 2001). Fires would destroy vegetation and other living organisms thereby disturbing their life cycles and resulting in reduced biodiversity both in terms of richness and evenness (Hobbs 2000; Sorrensen 2004).

Some respondents alluded that the observed trends in harvests were a result of community members cooking Mopani worms with their pot lids on. There were beliefs that this scenario drives the worms away with time. However we did not find any studies that either corroborated or disputed these beliefs and validated our findings. This area is not well researched but it should be noted that such beliefs have an impact on conservation of natural resources and these could be used as a basis for sustainable development (Negi 2010; Mary 2018; Winter 1997).

It should be noted that there was a sharp decline in Mopani worm harvests from 2007 to 2008 as compared to other successive years. Zimbabwe has experienced erratic rainfall patterns since early 2000 (Richardson 2009). The amount of rainfall received between the year 2007 and 2008 was reported to be below the expected normal rainfall levels (Nangombe 2015). This then explains the swift decline in Mopani worm harvests that rely on flourishing of Mopani trees.

\section{Limitations}

It was a challenge to collate and estimate Mopani worm yield as some yield records were missing, however triangulation through use of different data sources enabled estimates to be made. Respondents were probed of their estimated harvests from 2007 to 2016 it should be noted that recall bias was a potential confounder in this study therefore there is a possibility that some of the estimated quantities by the respondents themselves might not be true.

\section{Conclusions}

In conclusion findings of this study highlight that LULC changes impacted negatively on Mopani worm harvests over the period 2007 to 2016. A significant decline in vegetation cover as evidenced in the $\mathrm{LU}$ maps resulted in a decline in the Mopani worm quantities being harvested in the period under review. In light of these findings it is evident that LULC changes have resulted in loss of Biodiversity. It is also of paramount importance to note that major reasons for this decline have been associated with $\mathrm{LU}$ changes that are a result of human activities. There is therefore need for Natural Resource Conservation agencies to embark on awareness campaigns to encourage reforestation in degraded woodlands and also reduce or control cutting down of Mopani woodlands. There is also need to conduct research that would seek to determine the association between cultural beliefs and Mopani worm conservation and utilisation.

\section{Abbreviations}

GIS: Geographic Information Systems; LU: land use; LULC: land use-land cover; QGIS: Quantum Geographic Information System; SCP: Semi-Automatic Classification.

\section{Authors' contributions}

IN conceptualised the idea, collected data and produced LULC change maps. WNN refined the conceptualised idea, analysed data from respondents and drafted the manuscript. OD developed the research methods for respondents and reviewed the draft manuscript. AM developed research methods relating to mapping and did the map analysis (determining LULC change percentages) and reviewed the draft manuscript. NM developed the questionnaire that was used to collect data from respondents and translated it to local languages. The author also proof read the draft manuscript. All authors read and approved the final manuscript.

\section{Acknowledgements}

Not applicable.

\section{Competing interests}

The authors declare that they have no competing interests.

Availability of data and materials

Not applicable.

\section{Consent for publication}

Not applicable.

\section{Ethics approval and consent to participate}

High Levels of ethical considerations were observed. Permission to conduct the study was sought from the Department of Environmental Science and Health at the National University of Science and Technology. The Helsinki Declaration Principles on human ethics were applied. Permission was also sought from the participating Village Heads in all the wards where the study was conducted. Written consent was obtained from the participants and they were made aware that their participation was voluntary and they could opt out of the study at any given time without any explanation. Participants were not coerced or given tokens of appreciation for being part of the study. The questionnaires were translated into local languages that participants understood.

\section{Funding}

This research was not be funded.

\section{Publisher's Note}

Springer Nature remains neutral with regard to jurisdictional claims in published maps and institutional affiliations. 
Received: 19 February 2019 Accepted: 8 April 2019

Published online: 16 April 2019

\section{References}

Ajakaiye DOI, Mwabu GM (2010) Reproductive health, economic growth and poverty reduction in Africa: frameworks of analysis. Kenya, University of Nairobi Press, Nairobi

Beasley TW (2009) Poverty in Africa. Nova Science Publishers Inc, New York Chemura A, Kutywayo D, Chidoko P, Mahoya C (2016) Bioclimatic modelling of current and projected climatic suitability of coffee (Coffea arabica) production in Zimbabwe. Reg Environ Change 16:473-485

Chigonda T (2018) More than just story telling: a review of biodiversity conservation and utilisation from precolonial to postcolonial Zimbabwe. Scientifica. 2018:6214318

Chikuni A (1996) Conservation status of mopane woodlands in Malawi: a case study of Mua-Tsanya Forest Reserve. The Biodiversity of African Plants. Springer, New York

Child B (1996) Decentralization and biodiversity conservation: Zimbabwe. In Lutz E, Caldecott J (eds) Decentralization and biodiversity conservation. World Bank Symposium series. World Bank, Washington, D.C.

Clement RM, Horn SP (2001) Pre-Columbian land-use history in Costa Rica: a 3000-year record of forest clearance, agriculture and fires from Laguna Zoncho. Holocene 11:419-426

Dube E (2015a) Environmental challenges posed by veld fires in fragile regions: the case of the Bulilima and Mangwe districts in southern Zimbabwe. Jamba (Potchefstroom, South Africa) 7:224

Dube E (2015b) Improving disaster risk reduction capacity of District Civil Protection Units in managing veld fires: a case of Mangwe District in Matabeleland South Province, Zimbabwe. Jamba (Potchefstroom, South Africa) $7: 143$

Government of Zimbabwe (2016) Zimbabwe Demographic and Health Survey 2015 Final Report

Hobbs RJ (2000) Land-use changes and invasions. Invasive species in a changing world. pp 55-64

Makhado RA, Potgieter MJ, Wessels DCJ, Saidi AT, Masehela KK (2012) Use of Mopane woodland resources and associated woodland management challenges in rural areas of South Africa. Ethnobot Res Appl 10:369-379

Makhado R, Potgieter M, Timberlake J, Gumbo D (2014) A review of the significance of mopane products to rural people's livelihoods in southern Africa. Trans R Soc South Afr 69:117-122
Mary K (2018) Use of community cultural practices and beliefs in the conservation of Lake Baringo Ecosystem in Kenya. Int I Nat Resour Ecol Manag 3:32

Mataboge MS, Alders RG, Nkunika POY, Wenhold FAM, Dlamini NR, Mulaudzi FM (2016) Effects of climate variability on the harvesting and preservation of Mopani worms. Indilinga Afr J Indigenous Knowl Syst 15:34-38

Nangombe S. Drought conditions and management strategies in Zimbabwe. In: Proceedings of the regional workshops on capacity development to support national drought management policies for eastern and southern Africa and the near east and north Africa Regions, 2015. pp 84-89

Negi CS (2010) Traditional culture and biodiversity conservation: examples from Uttarakhand. SPIE, Central Himalaya

Potgieter M, Mushongohande M, Wessels D (2006) Mopane tree ecology and management

Potgieter M, Makhado R, Potgieter A (2012) Mopane worms

Richardson C (2009) How much did droughts matter? Linking rainfall and GDP growth in Zimbabwe

Ryan CM, Pritchard R, McNicol I, Owen M, Fisher JA, Lehmann C (2016) Ecosystem services from southern African woodlands and their future under global change. Philos Trans R Soc B 371(1703):20150312

Sorrensen C (2004) Contributions of fire use study to land use/cover change frameworks: understanding landscape change in agricultural frontiers. Hum Ecol 32:395-420

Thomas B (2013) Sustainable harvesting and trading of mopane worms (Imbrasia belina) in Northern Namibia: an experience from the Uukwaluudhi area AU-Thomas, Benisiu. Int J Environ Stud 70:494-502

Thompson C, Chishakwe N (2011) Drawing policy lessons from the impact and relationship of climate change, agro-fuels and modern biotechnology to agriculture and agro-biodiversity in southern Africa: the case of Malawi, Zambia and Zimbabwe/edited by Nyasha E. Chishakwe and Carol Thompson. [Harare]: Community Technology Development Trust

van Voorthuizen E (1976) The mopane tree. Botswana notes and records. pp 223-230

Ali AMS (2006) Rice to shrimp: Land use/land cover changes and soil degradation in Southwestern Bangladesh. Land Use Policy 23(4):421-435

Winter KA (1997) Conservation and culture: natural resource management and the local voice. J Ecol Anthropol 1:42-47

\section{Submit your manuscript to a SpringerOpen ${ }^{\circ}$ journal and benefit from:}

- Convenient online submission

- Rigorous peer review

- Open access: articles freely available online

- High visibility within the field

- Retaining the copyright to your article

Submit your next manuscript at $\boldsymbol{\nabla}$ springeropen.com 